\title{
PEMBERDAYAAN MASYARAKAT DESA SRENGAT DALAM PEMBUATAN ANTISEPTIK ALAMI DARI EKSTRAK DAUN MIANA
}

\author{
Afidatul Muadifah $^{1^{*}}$, Khoirul Ngibad ${ }^{2}$, Nabila Puteri Salsabela ${ }^{3}$ \\ ${ }^{1,3}$ STIKES Karya Putra Bangsa Tulungagung \\ 'Universitas Ma'arif Hasyim Latif Sidoarjo
}

Email Korespondensi: afidatul.muadifah@stikes-kartrasa.ac.id

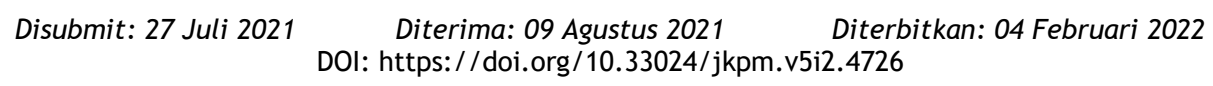

\begin{abstract}
ABSTRAK
Sulit diterapkan protokol kesehatan dalam upaya pencegahan covid-19 di Desa Srengat, karena memberikan pendidikan kepada masyarakat desa dengan latar belakang yang mayoritas adalah petani dan peternak (bukan akademisi) adalah cukup sulit. Mereka lebih mengedepankan kepercayaan dalam bertindak daripada menggunakan ilmu pengetahuan. Pada sisi lain, ketersediaan tempat mencuci tangan juga kurang memadai pada mayoritas rumah, sehingga membuat masyarakat semakin tidak terampil dalam mencuci tangan setelah keluar rumah ataupun ketika bertamu. Pengetahuan akan penggunaan antiseptik seperti handsanitizer masih rendah, dan sebagian masyarakat yang mengetahui lebih memperhitungkan biaya jika harus membelinya, sehingga membuat ketersediaan handsanitizer dirumah-rumah warga sangat terbatas padahal banyak masyarakat yang sudah menanam tanaman Miana yang berpotensi sebagai antiseptik. Tujuan dan metode: Meningkatkan pengetahuan masyarakat Desa Srengat tentang covid19 melalui penyuluhan, pemberdayaan Jam'iyah Yasin Desa Srengat dalam peningkatan jumlah tanaman miana melalui gerakan menanam, dan difusi ipteks serta pelatihan kepada Jam'iyah Yasin Desa Srengat dalam pembuatan produk gel handsanitizer dari ekstrak daun miana sebagai alternatif antiseptik alami dan diberikan secara gratis untuk masyarakat Desa Srengat. Hasil : Program penyuluhan berjalan dengan baik dengan adanya peningkatan pengetahuan masyarakat sebesar 60\%, tanaman Miana mengalami peningkatan hasil panen sebesar 62,5\% pada bulan ke-3, dan ketersediaan handsanitizer di Desa Srengat sudah cukup memadai (tersedia pada 40 Kartu Keluarga) sehingga dapat digunakan sebagai alternatif antiseptik alami pengganti cuci tangan.
\end{abstract}

Kata Kunci: Antiseptik Alami; Miana; Hand sanitizer; Desa Srengat

\begin{abstract}
It is difficult to apply health protocols in an effort to prevent covid-19 in Srengat Village, because providing education to village communities with backgrounds whose majority are farmers and ranchers (not academics) is quite difficult. They prioritize trust in action rather than using knowledge. On the other hand, the availability of a place to wash hands is also inadequate in the majority of homes, thus making people increasingly unskilled in washing their hands after leaving the house or when visiting. Knowledge of the use of antiseptics such as hand
\end{abstract}


sanitizers is still low, and some people who know are more aware of the costs if they have to buy them, thus making the availability of hand sanitizers in people's homes very limited even though many people have planted Miana plants which have the potential as antiseptics. Objectives and methods: Increasing the knowledge of the Srengat Village community about covid-19 through counseling, empowerment of Jam'iyah Yasin in Srengat Village in increasing the number of miana plants through planting movements, and the diffusion of science and technology as well as training for Jam'iyah Yasin in Srengat Village in making hand sanitizer gel products from miana leaf extract as an alternative to natural antiseptic and given free of charge to the people of Srengat Village. Results: The extension program went well with an increase in community knowledge of $60 \%$, Miana plants experienced an increase in yields of $62.5 \%$ in the $3 \mathrm{rd}$ month, and the availability of hand sanitizer in Srengat Village was sufficient (available on 40 Family Cards) so that can be used as an alternative to natural antiseptics instead of hand washing.

Keywords: Natural Antiseptic, Miana, Hand sanitizer, Srengat Village

\section{PENDAHULUAN}

Selama Pandemi Covid-19, ada keadaan darurat kesehatan masyarakat. Oleh karena itu, upaya pencegahan harus dilakukan sedini mungkin. Juru Bicara Gugus Tugas Penanganan Covid-19 Reisa Broto Asmoro mengimbau masyarakat untuk menerapkan 3M (Cuci tangan, jaga jarak dan menjauhi keramaian). Berdasarkan penelitian, tidak mencuci tangan dapat meningkatkan risiko menderita penyakit, tidak hanya Covid-19 tetapi juga penyakit lain yang disebabkan oleh bakteri, yaitu 95\% (Sinaga, L. R. V., Seri, A. M., \& Henny, A. B, 2020).

Di Desa Srengat sulit diterapkan protokol kesehatan dalam upaya pencegahan covid-19, karena memberikan pendidikan kepada masyarakat desa dengan latar belakang yang mayoritas adalah petani dan peternak (bukan akademisi) adalah cukup sulit. Mereka lebih mengedepankan kepercayaan dalam bertindak daripada menggunakan ilmu pengetahuan. Pada sisi lain, ketersediaan tempat mencuci tangan juga kurang memadai pada mayoritas rumah, sehingga membuat masyarakat semakin tidak terampil dalam mencuci tangan setelah keluar rumah ataupun ketika bertamu. Pengetahuan akan penggunaan antiseptik seperti handsanitizer masih rendah, dan sebagian masyarakat yang mengetahui lebih memperhitungkan biaya jika harus membelinya, sehingga membuat ketersediaan handsanitizer dirumah-rumah warga sangat terbatas.

Upaya mencuci/membersihkan tangan dapat dilakukan dengan menggunakan hand sanitizer (dalam formulasi gel) yang lebih efektif daripada mencuci tangan dengan air mengalir (Shu, 2013). Formulasi gel memiliki beberapa keunggulan yaitu memiliki daya sebar yang baik, tidak menyumbat pori-pori kulit, menimbulkan efek dingin karena lambatnya penguapan air pada kulit, dan pelepasan obat yang baik (Asngad, A., R. Bagas, A., \& Nopitasari, 2018). Gel hand sanitizer yang mengandung alkohol memiliki efektivitas yang lebih baik dalam menghambat mikroba dan membutuhkan waktu yang singkat, namun membuat kulit menjadi kering, iritasi (Widyawati, L., Mustariani, Aprilia, B. A., \& Purmafitriah, E, 2017).

Modifikasi gel pembersih tangan berbahan alami ini dinilai lebih aman dan tidak menyebabkan iritasi kulit. Di Indonesia, tanaman yang dapat 
digunakan sebagai alternatif antiseptik alami antara lain daun Miana. Dalam penelitian Muadifah dkk. (2022) menyatakan bahwa gel hand sanitizer kombinasi daun Miana dan daun Kemuning dengan perbandingan 15\%:5\% menunjukkan daya hambat sebesar 7,33 mm (terhadap Staphylococcus aureus) dan 09,00 mm (terhadap Escherichia coli) yang termasuk dalam kategori sedang. Hasil penelitian tersebut menunjukkan bahwa daun Miana memiliki efektivitas yang lebih bagus daripada daun Kemuning dalam menghambat pertumbuhan bakteri. Sehingga, dalam pengabdian masyarakat ini gel pembersih tangan yang dibuat berasal dari bahan alam daun Miana. Gel pembersih tangan (hand sanitizer) tersebut memenuhi persyaratan untuk uji organoleptik, homogenitas, $\mathrm{pH}$, kemampuan menyebar, dan adhesi, serta stabil selama penyimpanan. Selain itu hasil penapisan fitokimia ekstrak daun Miana menunjukkan kandungan alkaloid, dan tanin (Tarigan, I. L., Sari, A.K., Huda, C., Jovanncha, C., \& Muadifah, A, 2020). Ekstrak etanol daun Miana memiliki aktivitas antibakteri terhadap S.aureus, E. coli, dan P. Aeruginosa (Mpila, D., Fatimawali, \& Wiyono, W. I, 2012).

Tujuan dari kegiatan pengabdian masyarakat ini yaitu: Meningkatkan pengetahuan masyarakat Desa Srengat tentang covid-19 melalui penyuluhan, pemberdayaan Jam'iyah Yasin Desa Srengat dalam peningkatan jumlah tanaman Miana melalui gerakan menanam, dan difusi ipteks serta pelatihan kepada Jam'iyah Yasin Desa Srengat dalam pembuatan produk gel handsanitizer dari ekstrak daun miana sebagai alternatif antiseptik alami dan diberikan secara gratis untuk masyarakat Desa Srengat.

\section{MASALAH}

Wilayah Kabupaten Blitar terbagi menjadi dua bagian, yaitu bagian timur dan barat, Desa Srengat berada di Kabupaten Blitar bagian barat sebelum perbatasan dengan Kabupaten Tulungagung $( \pm 20 \mathrm{~km})$. Desa Srengat adalah desa di Kecamatan Srengat dengan lingkungan yang paling luas (Luas=53,98 $\mathrm{km}^{2}$ ) dibandingkan dengan Desa yang lain. Begitu juga dengan jumlah penduduknya yang mencapai 64.905 jiwa. Permasalahan yang pernah terjadi di masa pandemi ini yaitu dengan jumlah penduduk yang banyak membuat sulit diterapkannya protokol kesehatan dalam upaya pencegahan covid-19, karena memberikan pendidikan kepada masyarakat desa dengan latar belakang yang mayoritas adalah petani dan peternak (bukan akademisi) adalah cukup sulit. Mereka lebih mengedepankan kepercayaan dalam bertindak daripada menggunakan ilmu pengetahuan, seperti contoh kasus yaitu (1) Ada seorang warga yang ketika diperingatkan karena tidak menggunakan masker saat keluar rumah justru menjawab tegas dengan kepercayaan "hidup mati sudah ada yang mengatur, kalau memang waktunya terinfeksi covid-19 dan meninggal, itu sudah menjadi jatahnya". (2) Acara jam'iyah yasin, pada masa new normal semua kegiatan telah mulai dibuka dengan ketentuan sesuai protokol kesehatan, salah satunya jaga jarak. Akan tetapi pada kenyataannya hampir semua jama'ah yasin tidak ada yang mengikuti protokol tersebut. (3) Ketersediaan tempat mencuci tangan yang masih kurang memadai pada mayoritas rumah masyarakat Desa Srengat, sehingga membuat masyarakat semakin tidak terampil dalam mencuci tangan setelah keluar rumah ataupun ketika bertamu. (4) Pengetahuan akan penggunaan antiseptik seperti handsanitizer masih rendah, dan sebagian masyarakat yang mengetahui lebih memperhitungkan biaya jika harus 
membelinya, sehingga membuat ketersediaan handsanitizer dirumah-rumah warga sangat terbatas.

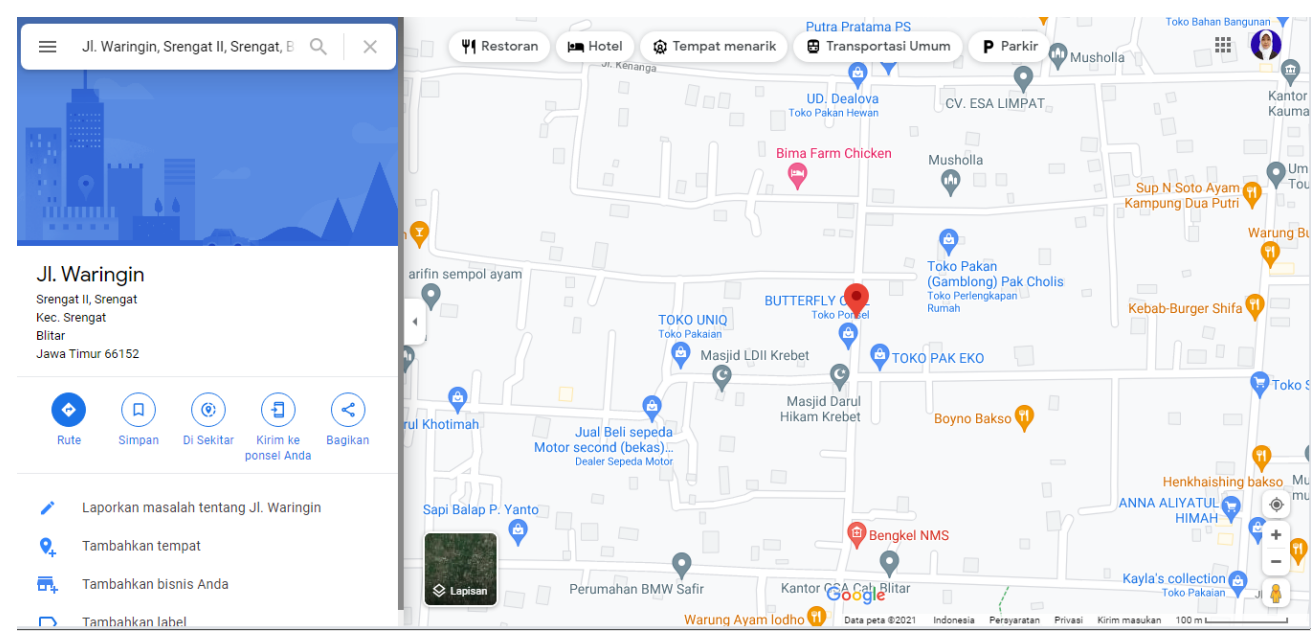

Gambar 1. Peta Lokasi Kegiatan Pengabdian Kepada Masyarakat.

\section{METODE}

Metode yang digunakan dalam kegiatan pengabdian masyarakat di Desa Krebet adalah sebagai berikut:

a) Pendidikan Masyarakat, untuk meningkatkan pengetahuan masyarakat Desa Srengat tentang covid-19 melalui penyuluhan.

b) Pemberdayaan, dalam meningkatan jumlah tanaman miana melalui gerakan menanam.

c) Difusi Ipteks serta pelatihan kepada Jam'iyah Yasin Desa Srengat dalam pembuatan produk gel handsanitizer dari ekstrak daun Miana sebagai alternatif antiseptik alami dan diberikan secara gratis untuk masyarakat Desa Srengat.

d) Evaluasi hasil program pengabdian masyarakat dengan melakukan monitoring untuk mengetahui sampai sejauh mana hasil yang dicapai dari kegiatan pendidikan, pemberdayaan, dan difusi ipteks serta pelatihan dalam pembuatan produk gel handsanitizer dari ekstrak daun miana sebagai alternatif antiseptik alami. Program berjalan dengan baik apabila ada peningkatan pengetahuan masyarakat sebesar $\geq 50 \%$, peningkatan hasil panen tanaman Miana sebesar $\geq 50 \%$ setiap 3 bulan, dan ketersediaan handsanitizer di Desa Srengat sudah cukup memadai ( $\geq 25$ Kartu Keluarga) sehingga dapat digunakan sebagai alternatif antiseptik alami pengganti cuci tangan.

\section{HASIL DAN PEMBAHASAN}

1. Pendidikan Masyarakat

Pendidikan masyarakat diberikan melalui kegiatan sosialisasi/penyuluhan, karena metode sosialisasi pencegahan penularan Covid -19 dapat meningkatkan pemahaman dan pengetahuan masyarakat (Ermawati dkk., 2021). Kegiatan pendidikan masyarakat melalui penyuluhan tentang covid-19 secara berkala dimulai dengan peran serta mitra dalam beberapa persiapan sebagai berikut: (a) penjadwalan 
dengan masyarakat Desa Srengat meliputi: waktu dan tempat penyuluhan, jumlah dan ketentuan umum peserta penyuluhan. (b) Penyebaran leaflet materi penyuluhan (sebagai pengganti undangan). (c) Motivator akan pentingnya hadir dalam acara penyuluhan.

Jumlah peserta maksimum 15 orang, dengan ketentuan mereka adalah anggota Jam'iyah Yasin Desa Srengat dengan pendidikan minimal SMA/sederajat dan bersedia mematuhi protokol kesehatan selama kegiatan penyuluhan. Motivasi yang diberikan oleh salah seorang dari pihak mitra yaitu dengan menjelaskan akan manfaat ilmu yang bisa diperoleh dari kegiatan penyuluhan dalam meningkatkan derajat kesehatan di masa pandemi Covid-19.

Evaluasi: dengan memberikan kuisioner pertanyaan sebelum dan sesudah materi penyuluhan diberikan guna mengetahui peningkatan pengetahuan masyarakat dengan ketentuan nilai: nilai A (86-100), B (7185), C (56-70), dan D $(<56)$, apabila $50 \%$ dari peserta mendapatkan peningkatan nilai ( $D$ menjadi $C$; $C$ menjadi $B$, dan B menjadi A), maka program dinyatakan berjalan dengan baik. Kuisioner diberikan kepada 15 peserta. Hasil analisis kuisioner sebelum dan sesudah kegiatan pembelajaran menunjukkan $60 \%$ dari peserta mengalami peningkatan pengetahuan (Gambar 2) yang dapat dilihat dari peningkatan nilai (Gambar 3), sehingga program pendidikan masyarakat dapat disimpulkan sudah berjalan dengan Baik.

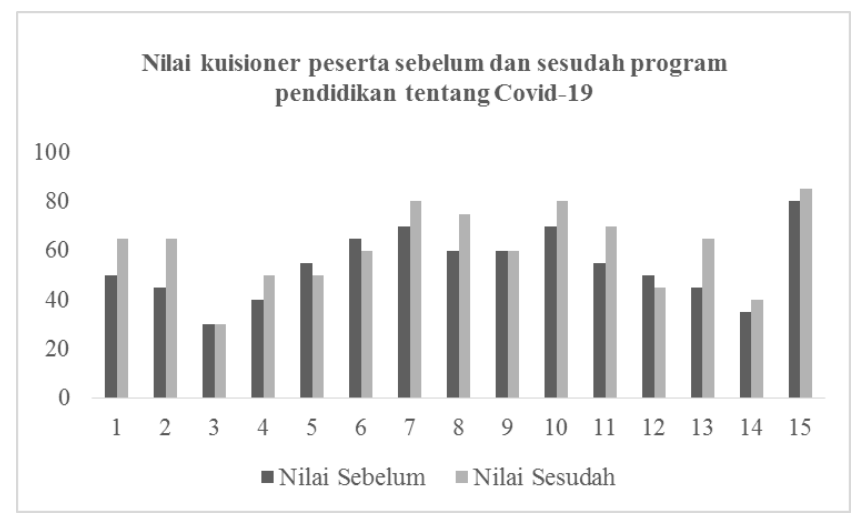

Gambar 2. Nilai kuisioner peserta sebelum dan sesudah program pendidikan tentang Covid-19

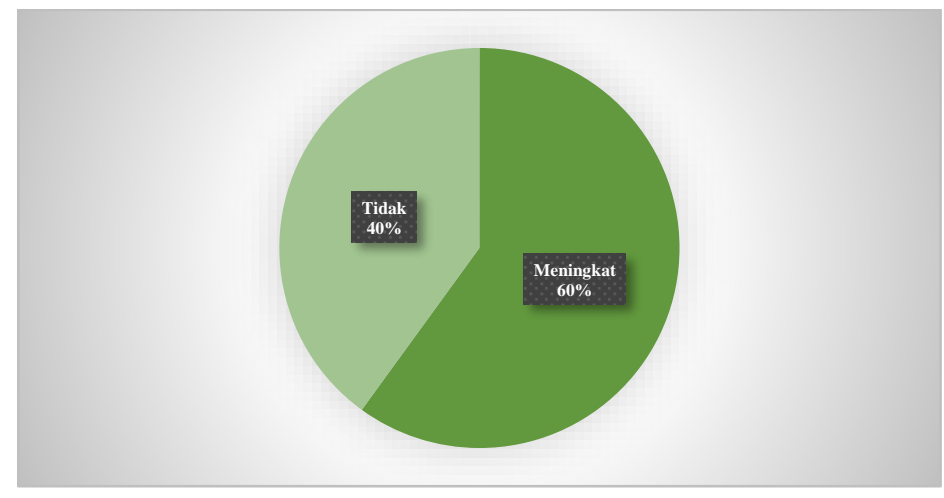

Gambar 3. Persentase peningkatan pengetahuan peserta pada program pendidikan tentang Covid-19 
2. Pemberdayaan Masyarakat

Mayoritas dari anggota Jam'iyah Yasin Desa Srengat yang menyukai tanaman hias Miana, telah memetik bibitnya dari rumah salah satu tim pengusul. Sehingga pada kesempatan tersebut tim pengusul berupaya memberikan informasi terkait manfaat Miana sebagai antiseptik (Gambar 4), yang kemudian tim pengusul bersama dengan mitra mulai memberdayakan masyarakat Desa Srengat untuk menanam Miana di rumah masing-masing dengan tujuan mempermudah dalam pengambilan sampel untuk pembuatan sediaan gel hansanitizer, mengingat tanaman Miana masih langka dan paling banyak tersebar di Wilayah Batu, Malang.

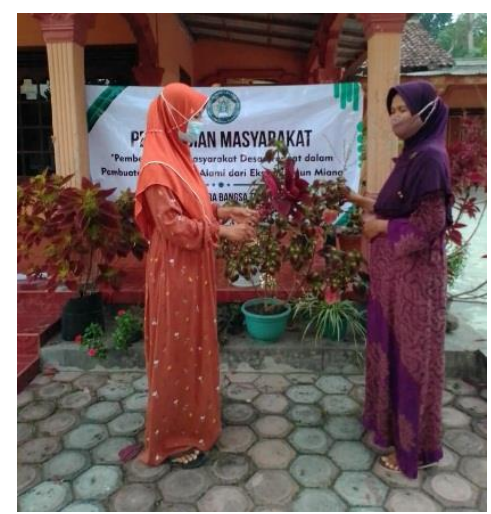

Gambar 4. Pemberian informasi terkait manfaat daun Miana sebagai antiseptik berikut:

Beberapa informasi yang telah diberikan yaitu sebagai

a) Pengertian antiseptik

Antiseptik merupakan suatu zat kimia yang memiliki kerja untuk menghancurkan mikroorganisme ataupun menghambat kerjanya, sehingga dapat mencegah terjadinya suatu infeksi. Antiseptik juga dapat dibedakan dengan antibiotik, di mana kerja dari antibiotik adalah spesifik dengan mikroorganisme tertentu, dan antiseptik kerjanya lebih umum (Al-Adham, I., Haddadin, R., Collier, P., 2013).

b) Manfaat daun Miana

Berdasarkan hasil penelitian yang telah dilakukan oleh Mpila dkk. pada tahun 2012, daun Miana memiliki aktivitas untuk menghambat mikroorganisme yaitu S.aureus, $E$. coli, dan $P$. Aeruginosa. Proses penghambatan pertumbuhan mikroorganisme dapat terjadi karena dalam daun Miana terdapat kandungan senyawa metabolit sekunder yaitu alkaloid dan tanin (Tarigan, I. L., Sari, A.K., Huda, C., Jovanncha, C., \& Muadifah, A, 2020).

Salah satu mekanisme kerja dari senyawa metabolit sekunder alkaloid dan tanin yaitu (1) Tanin: menghambat enzim reverse transkriptase dan DNA topoisomerase sehingga sel bakteri tidak dapat terbentuk (Nuria, M. C., Faizaitun., Arvin., \& Sumantri, 2009), (2) Alkaloid: mengganggu komponen penyusun peptidoglikan pada sel bakteri, 14 sehingga lapisan dinding sel tidak terbentuk secara utuh dan menyebabkan kematian sel tersebut (Darsana, I. Besung, I., \& Mahatmi, H., 2012). 
Antusiasme mitra dalam kegiatan menanam bersama cukup tinggi, hal tersebut didorong oleh kesukaan mitra terhadap keindahan dari tanaman Miana dan juga karena kesadaran mitra akan manfaat yang bisa diperoleh dari daun Miana tersebut. Sehingga saat ini (bulan ke-3) tanaman Miana bisa ditemui hampir di setiap rumah di Desa Srengat.

Banyaknya tanaman Miana yang ada di Desa Srengat, menunjukkan nilai yang linier dengan perolehan hasil panen daun Miana yaitu sebesar $5 \mathrm{~kg}$ pada bulan ke-0 dan menjadi $8 \mathrm{~kg}$ pada bulan ke-3 pasca kegiatan menanam bersama (Gambar 5). Hasil panen mengalami kenaikan lebih dari $50 \%$ yaitu sebesar $62,5 \%$ maka dapat dinyatakan bahwa program berjalan dengan baik.

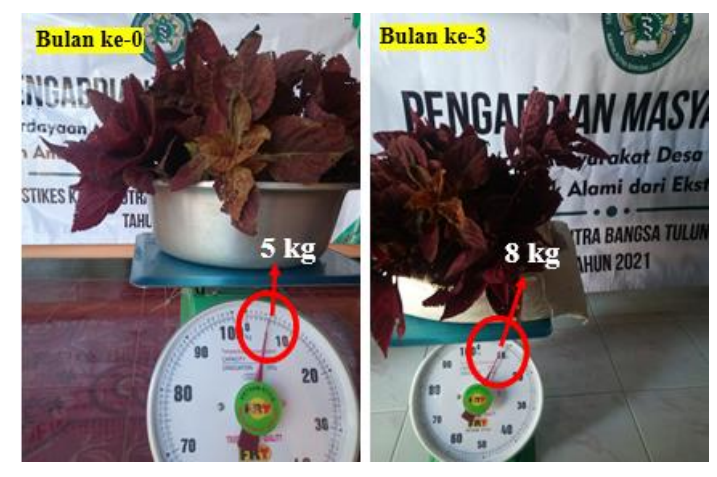

Gambar 5. Hasil panen daun Miana bulan ke-0 dan bulan ke-3

Peningkatan hasil panen memberikan banyak keuntungan baik bagi tim pengusul maupun pihak mitra. Tim pengusul membutuhkan banyak serbuk daun Miana untuk berbagai kegiatan penelitian di instansi STIKES Karya Putra Bangsa, sedangkan bagi mitra digunakan untuk pembuatan antiseptik alami. Sehingga, besar harapan dari kami agar bulan berikutnya hasil panen dapat meningkat secara signifikan.

\section{Difusi Ipteks dan Pelatihan}

Difusi ipteks adalah salah satu kegiatan yang ditujukan untuk dapat dihasilkannya suatu produk, yang mana dalam kegiatan pengabdian ini produk yang dihasilkan berupa antiseptik alami dari ekstrak daun Miana. Bentuk produk yang dihasilkan adalah berupa handsanitizer yang mana sangat bermanfaat bagi mitra pada khususnya dan bagi masyarakat Desa Srengat pada umumnya guna menjaga kebersihan tangan di masa Pandemi Covid-19.

Produk handsanitizer yang dihasilkan sudah melalui tahap pengujian laboratorium di STIKES Karya Putra Bangsa Tulungagung, yang mana terbukti menghambat pertumbuhan bakteri S. Aureus dan $E$. Coli, dan juga telah melalui tahap evaluasi sediaan, dengan hasil memenuhi persyaratan untuk uji organoleptik, homogenitas, $\mathrm{pH}$, kemampuan menyebar, dan adhesi, serta stabil selama penyimpanan. Sehingga, untuk saat ini produk handsanitizer aman digunakan untuk kalangan internal yaitu masyarakat Desa Srengat.

Pihak mitra dapat menghasilkan produk antiseptik alami dari ekstrak daun Miana, setelah memperoleh pelatihan dari tim pengusul. 
Kegiatan pelatihan dihadiri oleh tim pengusul dan 15 peserta dengan ketentuan yang sama seperti pada program pendidikan masyarakat (Gambar 6). Tujuan dari kegiatan pelatihan adalah untuk memberikan percontohan dalam pembuatan antiseptik alami dalam bentuk gel handsanitizer dari ekstrak daun Miana. Adapun formulasinya dapat dilihat pada Tabel 1.

Tabel 1. Formulasi standar dan formulasi antiseptik alami

\begin{tabular}{lcc}
\hline Bahan & \multicolumn{2}{c}{ Konsentrasi (\% b/v) } \\
& $\begin{array}{c}\text { Formulasi } \\
\text { standar }\end{array}$ & $\begin{array}{c}\text { Formulasi antiseptik } \\
\text { alami }\end{array}$ \\
\hline Ekstrak Miana & - & 15 \\
Carbomer 940 & 0,5 & 0,5 \\
Trietanolamine & 0,33 & 0,33 \\
Gliserin & 10 & 10 \\
Metil paraben & 0,3 & 0,3 \\
Propil paraben & 0,03 & 0,03 \\
Mentol & 0,08 & 0,08 \\
Aquadestilata & 60 & 60 \\
ad & & \\
\hline
\end{tabular}

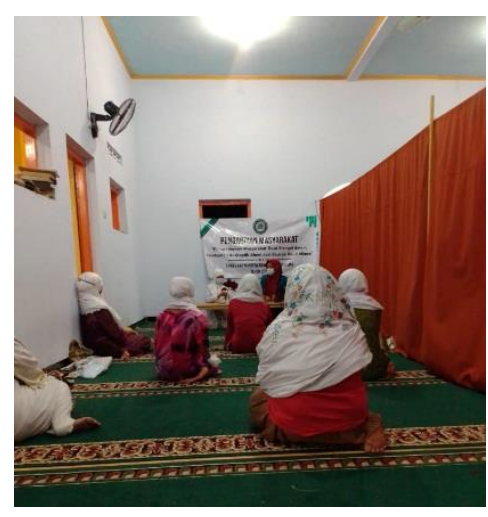

Gambar 6. Pelatihan pembuatan handsanitizer

Ketrampilan dalam membuat antiseptik alami dari ekstrak daun Miana telah dimiliki oleh semua peserta pelatihan, yang mana telah dihasilkan produk sebanyak 15 botol ukuran $25 \mathrm{~mL}$ pada saat pelatihan, dan 25 botol setelah pelatihan (pada bulan ke-3) sebagaimana dapat dilihat pada Gambar 7.

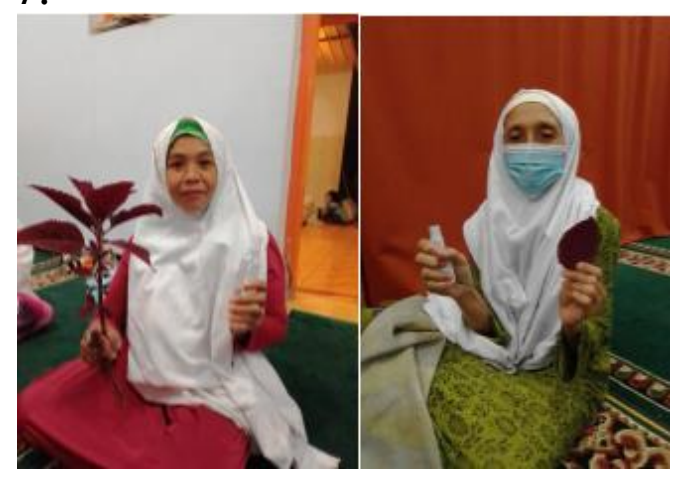

Gambar 7. Produk handsanitizer dari ekstrak daun Miana 
Produk handsanitizer yang diperoleh saat pelatihan dibagikan kepada semua peserta pelatihan, dan untuk 25 botol berikutnya dibagikan kepada 25 Kartu Keluarga masyarakat Desa Srengat secara gratis. Sehingga dapat dinyatakan bahwa program difusi ipteks dan pelatihan telah berjalan dengan baik. Sebagaimana dari hasil pengabdian masayarakat yang telah dilakukan oleh Ermawati dkk. (2021) bahwa pelatihan pembuatan hand sanitizer dari bahan alami berdampak besar terhadap peningkatan kreativitas masyarakat dalam memanfaatkan bahan alam disekitar rumah untuk peningkatan personal hygiene sebagai bahan pembuatan hand sanitizer. Adapun tujuan pembagian antiseptik alami ini adalah sebagai bentuk upaya pencegahan penularan Covid-19 melalui gerakan mencuci/membersihkan tangan secara efektif tanpa menggunakan air mengalir.

\section{KESIMPULAN}

Program pendidikan masyarakat telah menghasilkan peningkatan pemahaman dan pengetahuan tentang Covid-19 sebesar $60 \%$. Masyarakat Desa Srengat juga sudah terberdaya dalam menanam tanaman Miana di masing-masing tempat tinggalnya, sehingga hasil panen daun Miana meningkat $62,5 \%$ pada bulan ke-3. Hasil panen daun Miana dimanfaatkan untuk membuat produk handsanitizer yang dapat dibagikan kepada $40 \mathrm{Kartu}$ Keluarga masyarakat Desa Srengat sebagai alternatif antiseptik alami pengganti cuci tangan.

\section{DAFTAR PUSTAKA}

Al-Adham, I., Haddadin, R., Collier, P. (2013). Types of Microbicidal and Microbistatic Agents. Blacwell Publishing.

Asngad, A., R. Bagas, A., \& Nopitasari. (2018). Kualitas Gel Pembersih Tangan (Handsanitizer) dari Ekstrak Batang Pisang dengan Pemnambahan Alkohol, Triklosan dan Gliserin yang Berbeda Dosisnya. bioeksperimen, $\quad 4(2)$ 61-70. doi:https://doi.org/10.23917/bioeksperimen.v4il.2795

Darsana, I. Besung, I., \& Mahatmi, H. (2012). Potensi Daun Binahong (Anredera Cordifolia (Tenore) Steenis) dalam menghambat pertumbuhan Bakteri Eschericia coli secara in Vitro. Indonesia Medicus Veterinus.

Ermawati, N., Rahmawati, D., \& Restuti, A.N.S. (2021). Upaya Peningkatan Personal Higiene Masyarakat Melalui Pembuatan Hand Sanitizer Berbahan Alami. Jurnal Kreativitas Pengabdian Kepada Masyarakat (PKM). 4(1): 145-151.

Mpila, D., Fatimawali, \& Wiyono, W. I. (2012). Uji Aktivitas Antibakteri Daun Mayana (Coleus atropurpureus (L) Benth) Terhadap Staphylococcus aureus, Eschericia coli dan Pseudomonas aeruginosa secara in vitro. 13.

Muadifah, A., Tilarso, D.P., Kristijono, A., \& Salsabela, N.P. (2022). Hand Sanitizer Gel Modification Combination Of Miana And Kemuning Leaves Extract As A Natural Antiseptic Alternative. JI-KES: Jurnal IImu Kesehatan. 5(2).

Nuria, M. C., Faizaitun., Arvin., \& Sumantri. (2009). Uji Aktivitas Antibakteri Ekstrak Etanol Daun Jarak Pagar (Jatropha Curcas L) Terhadap Bakteri Satphylococcus aureus Atcc 25923, Escherichia Coli 
Atcc 25922 dan Salmonella Typhy Atcc 1408. Mediagro, 5(2), 26-37.

Shu, M. (2013). Formulasi Sediaan Gel Hand Sanitizer dengan bahan Aktif Triklosan 0,5\% dan 1 \%. Jurnal Ilmiah Mahasiswa Universitas Surabaya, 2(1), 1-14.

Sinaga, L. R. V., Seri, A. M., \& Henny, A. B. (2020). Sosialisasi Perilaku Cuci Tangan pakai Sabun di Desa Sawo Sebagai Bentuk Kepedulian Terhadap Masyarakat Di tengah Mewabahnya Virus Covid-19. Jurnal Abdimas mutiara, 1, 19-28.

Tarigan, I. L., Sari, A.K., Huda, C., Jovanncha, C., \& Muadifah, A. (2020). Phytochemical Screening and Quantitative Analysis of coleus Arthropurpureus Ethyl Acetat Fraction and Antibacterial Activity Against Staphylococcus aureus. ALKIMIA : Jurnal Ilmu Kimia dan Terapan , 4(1), 17-23.

Widyawati, L., Mustariani, Aprilia, B. A., \& Purmafitriah, E. (2017). Formulasi Sediaan Gel Hand Sanitizer Ekstrak Etanol Daun Sirsak (Annona muricata Linn) sebagai Antibakteri Terhadap Staphylococcus aureus. Jurnal Farmasetis, 6(2), 47-57. 